\title{
Implementation of Batho Pele Principles in an Educational District Office
}

\author{
Department of Business Management, \\ University of Limpopo, Turfloop Campus 0727, Republic of South Africa \\ charlotte.pietersen@ul.ac.za
}

\section{Doi:10.5901/mjss.2014.v5n3p253}

\begin{abstract}
The aim of the article is to evaluate the extent to which the eight Batho Pele principles in the Batho Pele White Paper are implemented when officials deliver administrative services to internal customers in an educational district in Limpopo Province, South Africa. All the officials $(N=52)$ and a random sample of educators $(N=50)$ drawn from the educational district participated in the study. A custom-made questionnaire was administered to the two groups of respondents. The internal consistency of the questionnaire is satisfactory (coefficient Alpha $=0.94$ ). The majority of respondents in both groups perceived the implementation of the principles as problematic (educators - all eight principles; officials - Consultation, Service Standards, Courtesy, Openness and Transparency, and Redress). However, their perceptions differ significantly on Access, Redress and Value for Money. Interventions should be implemented to train and motivate officials to comply with the principles in their dayto-day service delivery. The findings of the study demonstrated the importance of conducting research in individual educational districts to raise the awareness of decision-makers higher up in the hierarchy with regard to the shortfall in service delivery at grass roots level. Further research is needed to evaluate the implementation of the Batho Pele principles in other educational districts.
\end{abstract}

Keywords: Batho Pele principles, service delivery, educational districts, human resource management

\section{Introduction}

The focus of improving service delivery in the educational system in South Africa has shifted to the local administrative level and more specifically to educational districts.

An educational district is defined as an area of a province which is demarcated for administrative purposes. It is the first level administrative subdivision of a provincial education department (Government Gazette, 2013: 10). An important reason for this shift is that there is a growing understanding of the important role that the educational district has in policy implementation at grass-roots level to provide quality services to customers (Chinsamy, 2002; Government Gazette, 2013; Roberts, 2001).

Miller (2006: 2) identified two groups of educational district customers. The first group is external customers such as parents as "buyers" of educational services for their children. Educational district offices have an obligation towards their external clients to improve educational access and retention and to help schools to achieve excellence in teaching (Government Gazette, 2013: 18).

The second group is internal customers, the principals and teachers, who are employed a specific district. An educational district office provides services to these educators as employees of the Department of Education (Blaine, 2006). They provide managerial support to educators (Government Gazette, 2013). In addition, they are responsible for providing efficient routine personnel administrative services to educators (Fleisch, 2002). These services include keeping accurate personnel records, pay-role and benefit administration, and resolving personnel-related queries as quickly as possible (Roberts, 2001; Madison, 2005).

This implementation of national policies is also a core function of educational district offices (Praneeta, 2006). One of the policies that they have to implement is the Batho Pele Policy, and more particularly, the eight Batho Pele principles listed in the White Paper on Transforming Public Service Delivery (WPTPSD) (Republic of South Africa: 1997:15-22). The aim of implementing this policy in educational district offices is to provide an acceptable level of service as envisioned in the WPTPSD (Government of Internal Consulting Services, 2003).

In order to evaluate the extent to which government departments are implementing the eight Batho Pele principles at various service delivery points the Public Service Commission of South Africa conducted a comprehensive survey (Public Service Commission, 2000). Among the departments included in the survey were six of the nine provincial 
departments of education. However, the focus of the survey in the education departments was on compliance with the Batho Pele principles by school educators in their role as service providers, and only educational managers completed the questionnaires. The survey did not make provision for an evaluation of the implementation of the principles in situations in which educators, as internal customers, are recipients of personnel administration services provided by service providers (officials) in educational districts. The views of educators and officials on the implementation of the Batho Pele principles were also not compared.

Against this background the aim of the present study is to evaluate compliance with the Batho Pele principles by an educational district office in order to obtain baseline information on service delivery issues and to suggest recommendations on service delivery improvement.

The following research question was formulated: "Do the views officials (service providers) and educators (internal customers) in an educational district differ with regard to the implementation of the eight Batho Pele principles?"

More specifically, the objectives of the study are to describe the views of officials and educators in an educational district on the effective implementation of the Batho Pele principles and to compare the views of the two groups with regard to the effective implementation of the Batho Pele principles.

\section{Literature Review}

\subsection{The "Customer First" revolution}

A number of years before Sekoto and Van Staaten (1999) advocated the adoption of a customer-focused approach to improve the quality of service delivery in the public service, the South African government recognized the potential advantages that this paradigm offers and committed itself a "customer first" revolution. This approach is widely used in the private sector and focuses on, among other things, quality service delivery, easier and expanded access to services, and continuous improvement in business practices (Sims, 2001). The customer-focused approach was adopted by launching a number of initiatives aimed at improving service delivery in the public service sector to meet the needs of all South Africans. One such initiative is the WPTPSD, commonly known as the Batho Pele White Paper (Republic of South Africa, 1997).

Batho Pele is a Sesotho phrase that translates as "people first" (Moran, 2002: 7). The name was chosen to emphasize that the first and foremost duty of public service is to serve its customers. The WPTPSD includes both a policy framework and an implementation strategy to accelerate and improve service delivery to all South Africans. As such the White Paper is mainly concerned with how services are provided and to improve efficiency and effectiveness of service delivery.

The aim of the Batho Pele initiative is to get public servants to be service orientated, to strive for excellence in service delivery, commit themselves to continuous service delivery improvement, allow citizens to hold them accountable for the type of services they deliver and to adopt a citizen orientated approach to service delivery informed by eight principles (Briefing to the Portfolio Committee on the Batho Pele Programme for the Public Service, 2010). In order to achieve this aim, systems, procedures, attitudes, and behavior have to be developed within the public service to enhance customer service and meet the needs of customers. In other words, it strives to put "... the people first" (Republic of South Africa, 1997:12).

In the WPTPSD (Republic of South Africa, 1997: 26-29) an eight-step cycle is recommended to implement a service delivery improvement program, namely: identify the customer; establish the customer's needs and priorities; establish the current service baseline; identify the "improvement gap"; set service standards; gear up for delivery; announce service standards; and monitor service delivery against service standards and publish results.

\subsection{Batho Pele principles}

In order to achieve the abovementioned ideals, every department in the South African public service is obliged to implement the eight national service delivery principles, the Batho Pele principles, outlined in the Batho Pele White Paper (Moran, 2002; Republic of South Africa, 1997). 
Figure 1. Batho Pele Principles

\section{Consultation}

Citizens should be consulted about the level and quality of the public service they will receive and, wherever possible should be given a choice about services that are offered.

\section{Setting Service Standards}

Citizens should be told what level and quality of public services they will receive so that they are aware of what to expect.

3. Increasing Access

All citizens should have equal access to the services to which they are entitled.

4. Ensuring Courtesy

Citizens should be treated with courtesy and consideration.

5. Providing Information

Citizens should be given full, accurate information about the public services they are entitled to receive.

6. Openness and Transparency

Citizens should be told how national and provincial departments are run, how much they cost, and who is in charge.

7. Redress

If the promised standard of service is not delivered, citizens should be offered an apology, a full explanation and a speedy and effective remedy; and when complaints are made, citizens should receive a sympathetic, positive response.

\section{Value for Money}

Public service should be provided economically and efficiently in order to give citizens the best possible value for money.

The eight Batho Pele principles listed by The Department of Cooperative Governance (2010), Kroukamp (1999), Mubangizi, (2005), and the Republic of South Africa (1997) are summarized in Figure 1. The principles correspond with the following characteristics of a customer-focused approach: consulting service users, setting service standards, increasing access to all facilities, ensuring courtesy when dealing with customers, providing more useful information, increasing openness and transparency, rectifying mistakes and failures, and providing the best possible value for money (Arko-Cobbah, 2002).

\subsection{Assessing the implementation of the Batho Pele principles}

A critical element in improving the effectiveness of an organization is to assess its current level of functioning. One way to assess an organization's level of effectiveness is to focus on the accomplishment of its goals (Nel, Van Dyk, Haasbroek, Schultz, Sono \& Werner, 2011). A major goal in the public sector is to deliver quality services to customers. According to Makgoba (2006), the standard by which service delivery is assessed will always be the degree to which a local government is responsive to the needs of its customers. This suggests that a critical indicator of the quality of service delivery is the perceptions of customers with regard to how well their needs and expectations are met as well as their level of satisfaction (Ivancevic \& Matteson, 1996). With the customer at the center of service delivery, the Batho Pele White Paper makes provision for customers to give feedback on the services that they receive, also at the local service delivery points.

However, there is still a significant gap between the expectations and perceptions of customers with regard to the day-to-day services that they anticipate and what they receive in actual fact (Briefing to the Portfolio Committee on the Batho Pele Programme for the Public Service, 2010; Fourie \& de Jager, 2005). Service delivery is apparently also a problem for educators, as customers, in educational districts. Mohlala (2005), for example, obtained customers' views on the implementation of Batho Pele on the district education level in the Western Cape. He found that customers (educators) had lost confidence in the district administration officials and that the poor quality of services provided by these officials could be blamed, among others, for the ever lower morale of educators. Furthermore, in a 2006 address the Minister of Education, Ms Naledi Pandor, emphasized that many teachers complained about poor services provided by educational district offices.

Another crucial source of information on the implementation of the Batho Pele principles, and the improvement of service delivery, is the perceptions of officials who provide services to customers in the public service. It is stated in the WPTPSD (Republic of South Africa, 1997: 19) that: "An important aspect of encouraging customer-focused behaviour is to provide staff with opportunities to suggest ways of improving service..." As such, the views of officials at the local level of government are of particular importance (Moran, 2002). They are at the forefront of service delivery and the "...recurring theme of current government initiatives is the need to demonstrate that (their) performance is managed, measured and improved" (Van der Walt, 2006: 128). It is generally accepted that Batho Pele has the potential to bring 
about major changes in the way that public services are delivered (Schwella \& Rossouw, 2005). However, early research findings indicated that both the direction and the success of any social policy reforms (also the Batho Pele initiative) will be determined, to a large extent, on how frontline workers implement such policies, on their discretion, and how they participate in this process (Meyers, 1998). The quality of services provided also depends on how committed these service providers are towards customer satisfaction. These grass root level officials are far removed from the inspiring presence of those who gather around the national policy making fires. Thus, the quality of public service delivery will not improve unless the 'street level bureaucrats' who interact on a daily basis with customers successfully implement the Batho Pele principles.

Unfortunately, it would appear that although most public servants endorse the Batho Pele initiative the expected improvement of quality of service delivery in the public sector has not been realized (Briefing to the Portfolio Committee on the Batho Pele Programme for the Public Service, 2010; Rapea, 2004). The problem is that a policy framework "...that is in essence a theoretical instrument, would not automatically lead to improvements in service delivery" (Fourie \& de Jager, 2005: 231). In the first place, delivery failure occurs when officials at all levels of government fail to recognize opportunities to implement policy (Binza, 2005). Secondly, poor service delivery is blamed on officials' lack of commitment to implement policies (Von Holdt, 2003). Furthermore, the findings of a study by Sims (2001) show that quality service delivery in the public sector depends to a large extent on the competence and integrity with which officials discharge their duties. The public service is also characterized, for example, by a lack of consultation on the required service standards, lack of accurate and simple information on services and standards at which they are rendered, lack of responsiveness and insensitiveness towards customers' complaints, and discourteous staff (Republic of South Africa, 1997). Lastly, the findings of a study by the Public Protector suggested that public servants lack a sense of urgency; they handle complaints poorly, fail to adhere to prescripts; and are ineffective in managing paper flow (Mokgoro, 2003). These examples are all symptomatic of a public service culture in which the customer does not come first.

Every official at the district level in the Department of Education is also responsible for implementing the Batho Pele principles (Government Gazette, 2013, PeTje, 2005). Furthermore, at the educational district level officials who provide administrative services to educators are required to apply the principles in their day-to-day functioning. In the 1997 White Paper of Human Resource Development in the Public Service the South African government committed itself to the development of excellence in the provision of human resource management services (including personnel administration functions), and in fostering individual commitment and dedication in officials who provide these services (Penceliah \& Moodley, 2002). However, the findings of the Public Service Commission survey (Public Service Commission, 2000) indicated the provincial departments of education in general complied with only four of the Batho Pele principles, namely: Consultation, Information, Openness and Transparency, and Redress. The findings suggested that the Batho Pele policy had not yet affected the day-to-day quality of service delivery by front-line officials.

It is therefore imperative that educational districts, as front-line service providers, should assess their own internal functioning and processes. Research findings indicated that one of the recurrent features of effective educational districts is the emphasis placed on accountability for their own performance (Roberts, 2001). Roberts recommended that where needed, they should make use of outside expertise to gather data on their performance.

Some of the promising methods used to obtain information from customers as well as officials about specific services and service gaps at local levels of government, also in education, include surveys, individual interviews, and focus group interviews (PeTje, 200; Makgoba, 2006; Van der Walt, 2006). The district offices could use research findings as a basis for initiating programs to improve their functioning. On the other hand, developmental programs should focus on the needs of each individual district. This implies that the starting point for data gathering should be on the level of functioning of an individual educational district (Roberts, 2001).

To conclude, Batho Pele is a dynamic process, which aims at refocusing public services on the needs of customers (Mubangizi, 2005). However, efficient and effective service delivery can only be achieved if both officials and customers work together to ensure that Batho Pele is implemented, if it becomes an adopted practice in public service arena, and if regular monitoring, evaluation and reporting on service delivery is enforced. The views of customers and front-line staff (who has a major role in the serving the public directly or providing services to other parts of government) are useful sources of information on how to improve services to both internal and external customers (Meyers, 1998). Nonetheless, it is possible that the perceptions of service providers and customers may differ with regard to the implementation of the Batho Pele principles. It is argued that a promising way to monitor, evaluate and report on current service delivery in the public sector is to compare the perceptions of service providers and customers (the purpose of the present investigation). 


\section{Method}

\subsection{Research approach}

A cross-sectional, survey design was employed to collect data from the target populations within relatively a short time frame. Dehn, Reinikka and Svensson (2002) regard the micro-level survey as a useful tool to obtain policy-relevant information and to assess the quality of service delivery and performance of frontline officials in an education district office.

\subsection{Research hypotheses}

The following hypotheses are formulated for the purpose of the study:

- H0: There is no significant difference in the perceptions of officials and educators on the implementation of the Batho Pele principles.

- $\mathrm{H} 1$ : There is a significant difference in the in the perceptions of officials and educators on the implementation of the Batho Pele principles.

\subsection{Population and samples}

The national Department of Education is divided into nine provincial departments that in turn are subdivided into educational districts (Narsee, 2006). Districts usually have a full-time staff complement of about sixty officials (Roberts, 2001). The present study was conducted in one of the six educational district offices situated in one of the provinces in South Africa. For the purpose of confidentiality the names of the province and the district are withheld. At the time of the investigation the district office had a staff complement of fifty-two administrative staff members. The whole population of staff members participated in the study.

The district office under investigation provides services to educators in six educational circuits. Since the population of educators in the district is scattered over a large, mainly rural area, for practical purposes data had been gathered in one of the more accessible circuits. At the time of the investigation there were 501 educators employed in 29 schools in the circuit. The names of ten schools were randomly selected from this target population. A random sample of five respondents was drawn from each of the ten selected schools (a total of 50 respondents).

\subsection{Instrumentation}

A custom-made questionnaire, based on the description of the eight Batho Pele principles on the Batho Pele White Paper, was developed. The questionnaire included 32 items (four items on each of the principles). A four-point Likerttype response scale was used to measure the levels of implementation of each of the Batho Pele principles as perceived the two groups of respondents. Respondents were asked to indicate their perceptions on levels of implementation of the each of the Batho Pele principles on a scale in which: Seldom $=1$, Sometimes $=2$, Often $=3$, and Very often $=4$. The highest possible score for each eight of the scales in the questionnaire is 16 . An item analysis was carried out to test the psychometric properties of the instrument and an overall Cronbach Coefficient Alpha of 0.94 was measured.

The questionnaire was distributed and collected by hand. The purpose of the investigation was explained in a cover letter and respondents were assured of the confidentiality of the survey. They were also informed that the study was conducted for research purposes only, that the results would be used exclusively for grouped data analysis and reporting, and that their participation in the study were voluntary. All the respondents were willing to participate in the study with a resulting response rate of $100 \%$.

\subsection{Data analysis}

The data was entered into the Statistical Package for the Social Sciences (SPSS) Version 21.0 for Windows (SPSSSouth Africa). Descriptive statistics (means, standard deviations and percentages) were calculated and a two sample independent $t$-test was conducted to test the null hypothesis. 


\section{Findings}

The results of the study are summarized in Table 1 and Table 2.

Table 1. Respondents' perceptions on the implementation of the Batho Pele principles

\begin{tabular}{|l|l|c|c|c|c|}
\hline \multicolumn{1}{|c|}{ Principles } & Respondents & Seldom \% & Sometimes \% & Often \% & Very often \% \\
\hline 1.Consultation & Officials & 32.7 & 42.3 & 13.5 & 11.5 \\
2. Service Standards & Educators & 26.0 & 44.0 & 24.0 & 6.0 \\
3. Access & Officials & 21.1 & 44.2 & 21.1 & 13.5 \\
& Educators & 28.0 & 26.0 & 28.0 & 18.0 \\
4. Courtesy & Officials & 26.9 & 23.1 & 23.1 & 26.9 \\
& Educators & 28.0 & 44.0 & 22.0 & 6.0 \\
5. Information & Officials & 23.1 & 38.5 & 30.8 & 7.1 \\
6. Openness \& Transparency & Educators & 28.0 & 50.0 & 18.0 & 4.0 \\
7. Redress & Officials & 21.1 & 28.8 & 28.8 & 21.2 \\
& Educators & 24.0 & 44.0 & 26.0 & 6.0 \\
8. Value for Money & Officials & 57.7 & 23.1 & 7.7 & 11.5 \\
& Educators & 42.0 & 40.0 & 12.0 & 6.0 \\
& Officials & 25.0 & 36.5 & 32.7 & 5.8 \\
& Educators & 34.0 & 42.9 & 22.0 & 2.0 \\
\end{tabular}

Table 2. Independent samples t-test

\begin{tabular}{|c|c|c|c|c|c|c|}
\hline Principles & Respondents & $N$ & Mean & $\begin{array}{c}\text { Mean } \\
\text { Difference }\end{array}$ & $\begin{array}{c}\text { Std. } \\
\text { Deviation }\end{array}$ & $\begin{array}{c}\text { Sig. } \\
\text { (2-tailed) }\end{array}$ \\
\hline Consultation & $\begin{array}{l}\text { Officials } \\
\text { Educators }\end{array}$ & $\begin{array}{l}52 \\
50\end{array}$ & $\begin{array}{l}8.40 \\
7.66 \\
\end{array}$ & .74 & $\begin{array}{l}2.86 \\
2.81 \\
\end{array}$ & .19 \\
\hline Service Standards & $\begin{array}{l}\text { Officials } \\
\text { Educators }\end{array}$ & $\begin{array}{l}52 \\
50\end{array}$ & $\begin{array}{l}9.29 \\
8.66\end{array}$ & .63 & $\begin{array}{l}2.89 \\
2.87\end{array}$ & .27 \\
\hline Access & $\begin{array}{l}\text { Officials } \\
\text { Educators }\end{array}$ & $\begin{array}{l}52 \\
50\end{array}$ & $\begin{array}{c}10.15 \\
9.12 \\
\end{array}$ & 1.03 & $\begin{array}{l}2.84 \\
2.59 \\
\end{array}$ & .06 \\
\hline Courtesy & $\begin{array}{l}\text { Officials } \\
\text { Educators }\end{array}$ & $\begin{array}{l}52 \\
50\end{array}$ & $\begin{array}{c}10.00 \\
7.66 \\
\end{array}$ & 2.34 & $\begin{array}{l}3.19 \\
2.81 \\
\end{array}$ & $.00^{* *}$ \\
\hline Information & $\begin{array}{l}\text { Officials } \\
\text { Educators }\end{array}$ & $\begin{array}{l}52 \\
50\end{array}$ & $\begin{array}{l}9.85 \\
9.00 \\
\end{array}$ & .85 & $\begin{array}{l}2.67 \\
2.73 \\
\end{array}$ & .12 \\
\hline $\begin{array}{l}\text { Openness \& } \\
\text { Transparency }\end{array}$ & $\begin{array}{l}\text { Officials } \\
\text { Educators }\end{array}$ & $\begin{array}{l}52 \\
50 \\
\end{array}$ & $\begin{array}{l}8.62 \\
7.88 \\
\end{array}$ & .74 & $\begin{array}{l}2.84 \\
2.99 \\
\end{array}$ & .21 \\
\hline Redress & $\begin{array}{l}\text { Officials } \\
\text { Educators }\end{array}$ & $\begin{array}{l}52 \\
50\end{array}$ & $\begin{array}{l}8.65 \\
7.24\end{array}$ & 1.41 & $\begin{array}{l}2.73 \\
2.61\end{array}$ & $.009 * *$ \\
\hline Value for Money & $\begin{array}{l}\text { Officials } \\
\text { Educators }\end{array}$ & $\begin{array}{l}52 \\
50 \\
\end{array}$ & $\begin{array}{l}9.77 \\
7.46 \\
\end{array}$ & 2.31 & $\begin{array}{l}3.20 \\
2.31 \\
\end{array}$ & $.00^{\star \star}$ \\
\hline
\end{tabular}

** Significant differences on the 0.01 level between groups

The main findings of the study are discussed by first describing the perceptions of the officials and educators with regard to the implementation of the eight Batho Pele principles. The results in Table 1 show that the majority of educators indicated that all eight principles are "seldom" and "sometimes" complied with in the district office. In comparison, most of the officials indicated that five of the principles, namely Consultation (75\%), Service Standards (65.3\%), Courtesy (58.6\%), Openness and Transparency (80.8\%) and Redress (61.5\%) are "seldom" and "sometimes" implemented in the target district. On the principles of Access and Information half of the officials chose "seldom" and "sometimes" and the other half "often" and "very often". Many of the officials (63\%) also indicated that Value for Money is "often" and "very often" implemented. Most of the educators (88\%), on the other hand, do not think that they receive the best possible value for their money.

Secondly, the results of the t-test for independent samples are summarized in Table 2. It is evident from Table 2 
that differences in the perceptions of officials and educators are statistical significant at the 0.01 level (2-tailed) on three of the eight principles namely: Courtesy (0.00), Redress (0.009) and Value of Money (0.00). On the other five principles there are no statistical significant differences between the two groups of respondents.

\section{Discussion and Conclusion}

The findings of the present study provide support for the observations by Chinsamy (2002) and Roberts (2001) that research in individual educational districts is essential because the educational district has a key role to play in policy implementation to provide quality services to customers. It is clear that internal customers do not receive an acceptable level of service from frontline service providers in the targeted educational district. It would also appear that the service providers themselves are mostly aware that they do not serve their customers to the best of their abilities. This is probably the reason why the null hypothesis was only be rejected for three of the eight principles (Courtesy, Redress, and Value for Money).

Thus, although it is imperative that they increase their efforts to implement all the Batho Pele principles in the district, they should pay particular attention to:

- treat internal customers with courtesy and consideration;

- offer an apology, a full explanation and a speedy and effective remedy when complaints are made and to give a sympathetic, positive response when promised standards of service is not delivered to internal customers;

- provide economically and efficiently services in order to give customers the best possible value for their money.

The last point is of particular importance as the service providers in the educational district appear to be unaware of how large the gap is between the expectations of their customers with regard to getting the best possible value for their money and what they receive in actual fact.

In more general terms, the findings highlight the importance of using different sources of information, in particular the perceptions of internal customers and those who provide frontline services, to evaluate the functioning of service providers on the educational district level. Furthermore, the findings demonstrated the usefulness of obtaining information from these sources to inform provincial managers of the gaps between the perceptions of different role players in the educational arena. According to Fourie and de Jager (2005: 234): "Managers should be in the position to determine the existing scope of service delivery and standards, in order to allow them to determine deficiencies..." A starting point for the improvement of service delivery in education then is to become aware of the views of service providers and internal customers at grass roots level.

Managers on the provincial levels should also realize that their own views on the effective implementation of the Batho Pele principles might differ from the views of frontline personnel and internal customers. For example, the educational managers who participated in the previously mentioned Public Service Commission survey indicated that provincial departments of education in general complied with four of the Batho Pele principles, namely: Consultation, Information, Openness and Transparency, and Redress. However, the findings of the present study suggest that it is possible that none of the principles are adequately implemented on the district level and that that the government initiative to put "the people first" has not yet been realized in the day-to-day quality of service delivery by front-line officials.

In light of the previous discussion the following recommendation are suggested:

- In order to keep the Batho Pele initiative alive, service delivery should be a regularly item on the agendas of management review meetings in educational districts. All the staff members in an educational district should be also constantly reminded that the implementation of the Batho Pele principles involves more that just paying lip service to the Batho Pele policy framework. It should be emphasized that the Batho Pele principles form an integral part of their day-to-day functioning and that it is not just as an add-on to their main business.

- However, if poor service delivery is the result of a lack of competence, programs should be launched to develop the practical administrative and interpersonal skills of officials. Human resource management specialists and human behavioural scientists could, for example, be contracted to identify training needs and to develop and presents appropriate remedial training programs.

- Educational district offices should also pay serious attention to hold individual employees accountable for their performance. Their performance should be rigorously monitored and regularly evaluated. They should also receive recognition and suitable rewards (positive or negative as the case may be) for their performance and outputs. 
In conclusion, the present study focused on a typical educational district in one of the nine provinces. Further research is envisioned in other educational districts to expand baseline information on the implementation of the Batho Pele principles at grass root levels. It has to be emphasized that research on this topic is critical as it is the duty and social obligation of all researchers in this field to assist public servants on all levels of government in their journey on the road to "Batho Pele".

\section{References}

Arko-Cobbah, A. (2002). The citizen as consumer: role in policy-making. Journal of Public Administration, 37 (1): 55-69.

Binza, S.M. (2005). Developing a learning public organization and improving the productivity of public human resources. Journal of Public Administration, 40 (2): 105-120.

Blaine, S. (2006). South Africa: Pandor seeks rethink of district education offices. Business Day, October 3. [online] Available: http://www.read.org.za/News/tabid/1231/ct//Details/mid/2190/ltemID/182/Default. aspx

Briefing to the Portfolio Committee on the Batho Plele Programme for the Public Service. (2010). [online] Available: (d2zmx6mlqh7g3a.cloudfront.net/cdn/farfuture/x:1381177415/files/docs/100519bathopele-0.ppt

Chinsamy, B. (2002). Successful school improvement and the educational district office in South Africa: some emerging propositions. [online] Available: http://www.rti.org/pubs /Chinsamy_Full.pdf 1- 8.

Dehn, J., Reinikka, R. \& Svensson J. (2002). Survey tools for assessing service delivery. [online] Available: http://www.worldbank.org /research/projects/publicspending/tools/pswebsite.survey.toolkit.march3.2003.pdf.http://www.iies.su. se/ svenssoj /surveytools. pdf\#search= \%22public\% 20service \%20delivery $\% 20$ problems $\% 22$

Department of Cooperative Governance (2010). Generic Batho Pele Service Standards and implementation Framework for Local Government. Republic of South Africa.

Fleisch, B. (2002). Managing Educational change: The State and School Reform in South Africa. Sandown: Heinemann.

Fourie, L. de W. \& de Jager, J. (2005). Increasing customer satisfaction through enhancing service delivery: an internal marketing approach. Journal of Public Administration, 40 (3.1): 229-246.

Republic of South Africa. Government Gazette, 3 April 2013: 1- 34.

Government of Internal Consulting Services. (2003). A district improvement framework with special reference to school support by district officials. In DDSP: Improving the Quality of Primary Education. Pretoria: Department of Education.

Ivancevic, J. M. \& Matteson, M. T. (1996). Organizational Behaviour. (4th Ed). Chicago: Irwin.

Kroukamp. H. (1999). "Batho Pele": putting the citizen first in transforming public service delivery in a changing South Africa. International Review of Administrative Sciences, 65: 327-338.

Madison, D. (2005). Outsourcing human resource functions: the challenge and opportunity for hr professionals. The Five O'Clock News, May: 8-11.

Mohlala, T. (2005). "Trapped" by neglect. Mail and Guardian Online, 23 October 2006[online] Available: http://www.mg.co.za /articlePage .aspx ?articleid= 238609\&area=/theteacher/eacherfeatures/

Makgoba, S. (2006). Service delivery in district management areas: the case of district municipalities. Journal of Public Administration, 41 (2): 144-162.

Meyers, M. K. (1998). Gaining cooperation at the front lines of service delivery: Issues for the implementation of welfare reform. [online] Available: $\quad$ http://www.wkkf.org/DesktopModules/WKF_Dmaltem/ViewDoc.aspx?fld=PDFFile\&CID=162\&ListID=28\&ItemID $=1622838$ \&LanguagelD=0: $1-11$

Miller, S. (2006). Continuous improvement of public schools through ISO 9001: 2000. America Society for Quality: 1-4. [online] Available: http://www.asq.org/economic-case/markets/pdf/case-study-rusd-iso-9001.pdf

Mokgoro, J. (2003). Batho Pele policy review: final report and recommendations. [online] Available: http://www.sarpn.org.za /documents/d0000875/docs/Batho PelePolicyReviewFinal Report\& Recommendations.pdf : 1-35.

Moran, G. (2002). A Practical Guide to Administrative Justice. Justice College; Pretoria: 1-50.

Mubangizi, B. C. (2005). Improving service delivery in the new South Africa: some reflections. Journal of Public Administration, 40 (4.1): 633- 648 .

Narsee, H. (2006). The common and contested meanings of education district in South Africa. Doctoral thesis. Faculty of Education: University of Pretoria.

Nel, P. S., Van Dyk, P. S., Haasbroek, G .D., Schultz, H. B., Sono, T. \& Werner, A. (2011. Human resources management. (8th Ed). Southern Africa: Oxford

Pandor, N. (2006). Districts: Professional Centres of School Support. Address by the Minister of Education, Ms Naledi Pandor, MP, at the District colloquium, Johannesburg, 2 October 2006.

Penceliah, Y. \& Moodley, S. (2002). Serving the public in the new millennium: a South African perspective. Journal of Public Administration, 37 (1): 28-39.

PeTje, M. (2005). Service delivery for the Gauteng Department of Education. Circular 29, 24 May, Department of Education: Office for Standards in Education, Johannesburg: 1-4.

Praneeta, C. J. (2006). The Perceptions of the School Management Team Regarding the Institutional Development and Support of Officials. Dissertation: Department of Educational Management, University of Johannesburg. 
Public Service Commission. (2000). Survey with compliance with the Batho Pele policy. Pretoria. [online] Available: http://www.psc.gov.za/docs/reports/ 2000/survey/intro.pdf: 1-120.

Rapea, A.P. (2004). Linking performance management to Batho Pele. Service Delivery Review, 3 (2): 99.

Republic of South Africa. (). White Paper on Transforming Public Service Delivery. Government Gazette 388 (18340): 1-40.

Roberts, J. (2001). District Development - The New Hope for Educational Reform. Unpublished paper presented at a conference of the District Development Support Programme: Research Triangle Institute.

Schwella, E. \& Rossouw, A. (2005). Competencies for the senior management service in the South African public service: an evaluative assessment. Journal of Public Administration, 40 (4): 761-771.

Sekoto, M \& Van Staaten, F. (1999). Focusing on the customer in the public sector. Journal of Public Administration, 34 (2): 104 -123.

Sims, H. (2001). Public confidence in government and government service delivery. [online] Available: http://www.myschoolmonecole.gc.ca/Research/publications/pdfs/HarveySimms_e.pdf\#search=\%22public\%20service\%20delivery\%20problems\%22: 1-41.

Van der Walt, G. )2006). Managing local government performance: key considerations and challenges. Journal of Public Administration, 41 (2): 128-143.

Von Holdt, K. (2003_. Health services delivery who is responsible? Naledi Policy Bulletin, April: 4-5. 